\title{
ANALISIS MESIN INFERENSI FORWARD DAN BACKWARD CHAINING UNTUK DIAGNOSIS PENYAKIT AUTOIMUN BERBASIS WEB
}

\author{
Desy Permata Sari \\ Program Studi Teknik Informatika S1, Fakultas Teknologi Industri \\ Institut Teknologi Nasional Malang, Jalan Raya Karanglo km 2 Malang, Indonesia \\ dedespermatasari25@gmail.com
}

\begin{abstract}
ABSTRAK
Penyakit Autoimun merupakan penyakit yang menyerang sistem kekebalan tubuh manusia yang biasa terjadi pada kaum wanita. Autoimun merupakan gangguan sistem kekebalan tubuh akibat gagalnya pertahanan kestabilan kondisi tubuh. Penyakit autoimun ini menyebabkan kerugian bagi organ tubuh manusia karena dapat merusak organ-organ sel yang masih sehat dalam tubuh seseorang. Gejala penyakit autoimun kapan saja dapat menyerang tubuh dan mempengaruhi sistem kekebalan tubuh manusia.

Penelitian ini menggunakan metode forward chaining dan backward chaining. Forward Chaining merupakan metode pencarian kesimpulan berdasarkan pada fakta yang ada menuju ke kesimpulan, Backward chaining merupakan pencarian yang arahnya kebalikan dari Forward Chaining. Proses pencarian dimulai dari tujuan, yaitu kesimpulan yang menjadi solusi permasalahan yang dihadapi.

Berdasarkan uji data hasil konsultasi menggunakan metode forward chaining dan backward chaining memiliki keakuratan yang sesuai dengan aturan yang ada. Pengujian fungsional sistem pakar ini dapat berjalan dengan baik pada web browser mozilla firefox, google chrome, dan microsoft edge.
\end{abstract}

Kata kunci : Sistem Pakar, Autoimun, Forward Chaining, Backward Chaining.

\section{PENDAHULUAN}

\subsection{Latar Belakang}

Penyakit Autoimun merupakan penyakit yang menyerang sistem kekebalan tubuh manusia yang biasa terjadi pada kaum wanita. Autoimun merupakan gangguan sistem kekebalan tubuh akibat gagalnya pertahanan kestabilan kondisi tubuh, sehingga sistem imun menyerang tubuh yang sehat dianggap sebagai benda asing yang harus dimusnahkan. Penyakit autoimun ini menyebabkan kerugian bagi organ tubuh manusia karena dapat merusak organ-organ sel yang masih sehat dalam tubuh seseorang. Contoh penyakit Autoimun yang paling sering ditemukan diantaranya Artritis Reumatoid, Lupus Eritematosus Sistematik, Penyakit Seliak, Sindrom Sjorgen, Polomialgia Reumatika, Sklerosis Multipel, Spondilitis Ankilosa, Diabetes Tipe 1, Alopesia Areata, Radang Pembuluh Darah, Arteritis Temporalis dan lain sebagainya.

Munculnya penyakit autoimun membuat timbulnya beberapa penyakit yang gejalanya sulit untuk diketahui dan dapat menyerang siapa saja terutama wanita. Gejala penyakit autoimun kapan saja dapat menyerang tubuh dan mempengaruhi sistem kekebalan tubuh manusia. Pada umumnya wanita menganggap gejala yang dialami hanya hal yang biasa saja dan menganggap remeh masalah tersebut, tetapi ketika sudah menyadari bahwa sudah masuk dalam fase yang kritis baru berinisatif untuk berkonsultasi ke dokter dan menyebabkan penanganan yang terlambat. Saat tubuh sudah terasa tidak bugar seharusnya mengambil langkah yang cepat untuk melakukan tindakan serta berkonsultasi atau berkunjung ke dokter, sehingga penyakit yang menyerang seseorang tidak sampai parah dan dapat dicegah terlebih dahulu. Untuk mempermudah mencegah dan mengetahui penyakit autoimun dari beberapa gejala yang di alami seseorang dibuatlah sebuah aplikasi untuk dapat mengetahui apakah seseorang tersebut terserang salah satu penyakit autoimun atau tidak.

Berdasarkan hal tersebut, akan dibuat Analisis Mesin Inferensi Forward dan Backward Chaining Untuk Diagnosis Penyakit Autoimun Berbasis Web. Untuk mempermudah kaum wanita mengenali sistem kekebalan tubuhnya apakah terserang salah satu penyakit yang digolongkan sebagai autoimun atau tidak. Proses diagnosis penyakit dilakukan dengan menggunakan metode Forward Chaining dan Backward Chaining. Forward Chaining mengumpulkan fakta-fakta penyakit yang dialami untuk mendapatkan kesimpulan dari fakta tersebut. Penalaran ini berdasarkan fakta yang ada, metode ini adalah kebalikan metode Backward Chaining, dimana metode ini dijalankan dengan mengumpulkan fakta-fakta yang ada untuk menarik kesimpulan. 


\subsection{Rumusan Masalah}

Berdasarkan latar belakang di atas, dapat dirumuskan permasalahan sebagai berikut :

1. Bagaimana mendeteksi salah satu penyakit autoimun berdasarkan gejala yang dialami seseorang.

2. Bagaimana menerapkan metode Forward Chaining dan Backward Chaining untuk menentukan salah satu penyakit autoimun berdasarkan gejala.

3. Bagaimana menerapkan metode Forward Chaining dan Backward Chaining dalam sebuah sistem.

\subsection{Tujuan}

Tujuan Penelitian Analisis Mesin Inferensi

Forward dan Backward Chaining Untuk Diagnosis Penyakit Autoimun Berbasis Web sebagai berikut :

1. Mendeteksi dalam penentuan macam dan jenis penyakit autoimun yang dialami seseorang.

2. Menerapkan Analisis Mesin Inferensi Forward dan Backward Chaining Untuk Diagnosis Penyakit Autoimun Berdasarkan Gejala Berbasis Web.

3. Menerapkan metode Forward Chaining dan Backward Chaining dalam sebuah sistem.

\subsection{Batasan Masalah}

Adapun batasan masalah dari pembuatan aplikasi sistem pakar menggunakan metode Forward Chaining dan Backward Chaining ini adalah :

1. Data set yang digunakan dalam penelitian ini merupakan data yang diambil dari seorang dokter yang memahami ilmu di bidang tersebut yaitu Ibu dr. Pramoda Wardhany, serta bertempat praktek di Nazar General Practice Physicians di Jl. Sudimoro, Mojolangu, Lowokwaru, Kota Malang.

2. Parameter data yang digunakan dalam penelitian sistem sistem pakar ini adalah:
a. Id gejala
b. Gejala
c. Id penyakit
d. Penyakit

3. Batasan penyakit yang digunakan dalam sistem ini ada 11 yaitu sebagai berikut :
a. Artritis Reumatoid
b. Lupus Eritematosus Sistematik
c. Penyakit Seliak
d. Sindrom Sjogren
e. Polimialgia Reumatika
f. Sklerosis Multiple
g. Spondilitis Ankilosa
h. Diabetes Tipe 1
i. Alopesia Areata
j. Radang Pembuluh Darah

\section{k. Arteritis Temporalis}

4. Studi Kasus yang digunakan pada skripsi ini diambil dari seorang dokter yang memahami tentang penyakit autoimun dengan melakukan wawancara secara langsung untuk mendapatkan data yang akurat dari dokter secara langsung yang digunakan untuk penelitian ini, metode yang digunakan dalam penelitian ini adalah metode Forward Chaining dan Backward Chaining, Forward Chaining digunakan untuk diagnosa awal pada penyakit dengan pelacakan dari gejalagejala yang diderita, sedangkan Backward Chaining pelacakan dimulai dengan pendekatan penyakit akan mencari gejalagejala yang memiliki kesimpulan yang mengarah pada penyakit.

5. Target pengguna sistem pakar ini untuk dokter dan pasien yang mengalami gejalagejala yang tergolong dalam penyakit autoimun.

6. Sistem pakar berbasis web yang dirancang menggunakan bahasa pemrograman $P H P$, database MySQL dan bootsrap sebagai css.

\section{TINJAUAN PUSTAKA}

\subsection{Penelitian Terkait}

Peradaban dunia yang semakin maju dan modern membuat mudah semua orang melakukan aktivitas apa saja, sehingga semua orang ingin serba cepat sampai makanan juga ingin siap saji tanpa memperhatikan kesehatan tubuh setelah mengkonsumsi makanan siap saji. Kita sebagai konsumen harus pintar dan jeli memilih makanan apakah makanan tersebut baik atau tidak bagi kesehatan tubuh. Karena butuh waktu jangka panjang untuk mengetahui kita terkena suatu penyakit parah atau tidak, bahkan penyakit di era sekarang selain banyak penyakit baru obatnya pun masih terbilang langka. Contohnya seperti penyakit Tuberkulosis, Tuberkulosis adalah suatu penyakit menular berbahaya yang disebabkan dari kelompok Mycobacterium, yaitu Mycobacterium Tuberkulosis. Setiap penderita dapat menularkan penyakit tersebut kepada orang terdekatnya. Peneliti Windah Supartini \& Hindarto tahun 2016 tertarik melakukan penelitian Sistem Pakar Berbasis web untuk mendiagnosis Penyakit Tuberkulosis di Jawa Timur. Permasalahan yang dihadapi meningkatnya pasien Tuberkulosis setiap tahunnya bahkan permenitnya dalam sehari dapat merenggut nyawa seseorang dan Indonesia menempati urutan ke 3 didunia setelah Indian dan China. Masalah ini dapat ditekan dengan adanya tindakan dini gejala TB, sehingga dibutuhkan sistem untuk mendiagnosa penyakit TB oleh seorang peneliti. [1] 
Sistem syaraf pusat mempunyai peran penting dalam mengatur berbagai aktivitas tubuh untuk menjalankan aktivitas motorik maupun sensorik diperlukan jaringan syaraf. Sistem sensorik mengumpulkan informasi yang akan diproses di otak dan diteruskan ke sistem motorik untuk mengontrol gerakan, aktivitas visceral, dan fungsi-fungsi endokrin. Peneliti Daniel Alexander Octavianus Turang tahun 2018 melakukan penelitian aplikasi sistem pakar berbasis web diagnosa penyakit syaraf pusat dengan metode forward chaining dikarenakan pentingnya sistem syaraf pusat bagi seseorang guna menjaga keseimbangan tubuh seseorang, dimana apabila ada gangguan maka akan terganggu pula organ tubuh yang lain, jadi dibuatlah aplikasi tersebut untuk mengetahui gejala, pengobatannya serta cara penyembuhannya. Metode ini mengikuti pola pelacakan maju. Pohon pelacakan ini dimulai dengan memberikan pertanyaan tentang gejala yang dimiliki, yang dimasukkan oleh user itu sendiri sampai diporoleh kesimpulan penyakit yang dialami oleh user. Serta adanya proses didalamnya yang disebut sebagai Depth-First Search yang akan menelusuri kaidah secara mendalam. [2]

Tidak jauh dari pembahasan sebelumnya di review ini membahas tentang autis. Autisme adalah gangguan perkembangan pada anak yang gejalanya sudah timbul sebelum anak tersebut mencapai usia tiga tahun. Dimana autis tersebut merupakan penyakit yang menyerang sistem saraf dimana sistem saraf tersebut melemah sehingga pada anak-anak usia dini mengalami perlambatan dalam tumbuh kembangnya, orang tua pun menjadi khawatir dikarenakan autis tersebut sulit diketahui karena banyak faktor serta gejala yang dapat menyebabkan anak kecil bisa menjadi autis. Dalam mengatasi masalah ini Lido Sabda Lesmana tahun 2017 Menerapkan Metode Forward Chaining untuk Mendiagnosa Gangguan Autis pada anak berbasis Android, dengan memanfaatkan sistem pakar, diharapkan bisa membangun sistem informasi berbasis android yang bisa diakses dimanapun dan kapanpun dengan syarat harus terkoneksi dengan jaringan internet. [3]

Penerapan sistem pakar diagnosa penyakit ginjal pada manusia menggunakan metode forward chaining oleh peneliti Samsilul Azhar dkk tahun 2014 dikarenakan adanya kesulitan dalam menentukan gejala penyakit ginjal, dimana fungsi ginjal dalam tubuh manusia sangat penting untuk menopang metabolisme seseorang. Karena banyak data kesehatan gagal ginjal juga menjadi penyakit paling berbahaya dikarenakan pola hidup yang tidak sehat. Adapun salah satu faktornya seperti telat makan serta makanan yang tidak sehat dan gaya hidup yang sering begadang dapat menyebabkan sesorang terkena gagal ginjal. Faktor lainnya pun juga ada seperti faktor sosial ekonomi juga dapat menjadikan salah satu faktor apabila tingkat kesejahteraan seseorang baik maka gaya hidup mendapat asupan yang cukup, begitu pun sebaliknya. Oleh karena itu peneliti berinisatif untuk membuat suatu sistem pakar guna mempermudah agar dapat lebih efisien dan efektif. [4]

Padi merupakan kebutuhan bahan pokok manusia terutama padi yang telah diolah menjadi nasi. Selain mengkonsumsi nasi beberapa orang juga mengkonsumsi ubi sebagai pengganti nasi. Banyaknya permintaan beras setiap tahunnya disebabkan banyaknya peningkatan angka penduduk Indonesia menyebabkan Indonesia kekurangan stok beras yang mengharuskan Indonesia mendapat pasokan beras dari luar negeri. Sebenarnya kita dapat memanen beras dengan jumlah besar dari hasil dalam negeri namun sangat disayangkan mudahnya tanaman padi terjangkit hama yang dapat menyebabkan kegagalan panen yang dikarenakan petani sering mengabaikan akibat ketidaktahuannya dan menganggap gejala penyakit pada padi hal yang biasa. Sehingga Peneliti Anton Setiawan Honggowibowo tahun 2009 membuat sistem pakar diagnosa penyakit padi menggunakan forward chaining berbasis web guna untuk memberi kemudahan untuk petani dalam mencegah terjadinya kegagalan panen yang disebabkan oleh penyakit yang ada pada petani agar dapat dideteksi lebih dini, sehingga para petani tidak harus menunggu lama untuk mendatangkan seorang pakar tani dalam menanggulangi padi yang terserang penyakit. [5]

\subsection{Sistem Pakar}

Pakar adalah orang yang mempunyai knowledge atau pengetahuan dan keahlian khusus yang dimiliki dalam menangani sebuah masalah tertentu. Sistem pakar yaitu sistem yang dirancang untuk dapat menyelesaikan suatu permasalahan yang bentuknya hampir sama atau meniru kerja dari para ahli atau dokter pakar yang biasa dalam menangani permasalahan tersebut. Tujuan perancangan sistem pakar untuk mempermudah kerja dalam menentukan suatu penyakit autoimun berdasarkan gejala-gejala yang dialami. Sistem pakar terbagi dari 2 bagian utama yaitu lingkungan pengembangan sistem pakar digunakan untuk memasukkan pengetahuan ke dalam lingkungan sistem pakar dan lingkungan konsultasi digunakan oleh pengguna yang bukan pakar guna memperoleh pengetahuan pakar. [6] 


\subsubsection{Forward Chaining}

Forward chaining akan di mulai dengan data yang tersedia dan menggunakan aturan yang telah dibuat untuk mendapatkan data yang lain sampai sasaran atau kesimpulan didapatkan. Metode Forward Chaining merupakan metode yang sering digunakan untuk proses yang memulai penalarannya berdasarkan pada fakta yang ada atau gejala dari suatu penyakit yang dipilih menuju kesimpulan. [7]

\subsubsection{Backward Chaining}

Metode backward chaining merupakan metode pencarian yang arahnya kebalikan dari forward chaining. Proses pencarian dimulai dari tujuan atau kesimpulan yang menjadi solusi permasalahan. Mesin inferensi mencari kaidahkaidah dalam basis pengetahuan yang kesimpulannya merupakan solusi yang ingin dicapai, kemudian dari kaidah-kaidah yang di peroleh, masing-masing kesimpulan di runut balik yang mengarah pada kesimpulan tersebut. [9]

\section{METODE PENELITIAN}

\subsection{Data Penyakit Autoimun}

\subsubsection{Penyakit} tabel 3.1.

Daftar data penyakit autoimun seperti pada

Tabel 3.1 Tabel penyakit

\begin{tabular}{|l|l|l|}
\hline No & $\begin{array}{c}\text { Id } \\
\text { Penyakit }\end{array}$ & \multicolumn{1}{|c|}{ Nama Penyakit } \\
\hline 1 & P001 & Artritis reumatoid \\
\hline 2 & P002 & Lupus eritematosus sistemik \\
\hline 3 & P003 & Penyakit seliak \\
\hline 4 & P004 & Sindrom sjogren \\
\hline 5 & P005 & Polimialgia reumatika \\
\hline 6 & P006 & Sklerosis multipel \\
\hline 7 & P007 & Spondilitis ankilosa \\
\hline 8 & P008 & Diabetes tipe 1 \\
\hline 9 & P009 & Alopesia areata \\
\hline 10 & P010 & Radang pembuluh darah \\
\hline 11 & P011 & Arteritis temporalis \\
\hline
\end{tabular}

\subsubsection{Gejala}

Daftar data gejala dari penyakit autoimun seperti pada tabel 3.2.

Tabel 3.2 Tabel gejala

\begin{tabular}{|l|l|l|}
\hline No & $\begin{array}{c}\text { Id } \\
\text { Gejala }\end{array}$ & \multicolumn{1}{c|}{ Nama Gejala } \\
\hline 1 & G001 & Nyeri sendi \\
\hline 2 & G002 & Tubuh lelah \\
\hline 3 & G003 & Sendi kaku \\
\hline 4 & G004 & Pembengkakan sendi \\
\hline 5 & G005 & Benjolan pada kulit \\
\hline 6 & G006 & Bengkak di jari tangan \\
\hline
\end{tabular}

\begin{tabular}{|l|l|l|}
\hline 7 & G007 & Nyeri bahu \\
\hline 8 & G008 & Nyeri leher \\
\hline 9 & G009 & Mata kemerahan \\
\hline 10 & G010 & Nyeri otot \\
\hline 11 & G011 & Tubuh anemia \\
\hline 12 & G012 & Kemerahan pada kulit \\
\hline 13 & G013 & Nyeri tajam di da \\
\hline 14 & G014 & Tubuh demam \\
\hline 15 & G015 & Mulut ulkus \\
\hline 16 & G016 & Kulit ruam \\
\hline 17 & G017 & Rambut rontok \\
\hline 18 & G018 & Penurunan berat badan \\
\hline 19 & G019 & Sakit kepala \\
\hline 20 & G020 & Mual \\
\hline 21 & G021 & Muntah \\
\hline 22 & G022 & Nyeri daerah perut \\
\hline 23 & G023 & Kembung \\
\hline 24 & G024 & Buang gas berlebihan \\
\hline 25 & G025 & Bersendata \\
\hline 26 & G026 & Diare \\
\hline 27 & G027 & Gangguan pencernaan \\
\hline 28 & G028 & Kesemutan \\
\hline 29 & G029 & Mulut kering \\
\hline 30 & G030 & Kehilangan indra perasa \\
\hline 31 & G031 & Gigi berlubang \\
\hline 32 & G032 & Suara serak \\
\hline 33 & G033 & Tenggorokan kesulitan menelan \\
\hline 34 & G034 & Batuk kering \\
\hline 35 & G035 & Kulit kering \\
\hline 36 & G036 & Pembengkakan kelenjar bening \\
\hline 37 & G037 & Otot tegang \\
\hline 38 & G038 & Nyeri punggung \\
\hline 39 & G039 & Nyeri mata \\
\hline 40 & G040 & Penglihtaan kabur \\
\hline 41 & G041 & Haus berlebihan \\
\hline 42 & G042 & Sering terasa lapar \\
\hline 43 & G043 & Buang air kecil berlebihan \\
\hline 44 & G044 & Lekukan kecil di kuku \\
\hline 45 & G045 & Nyeri rahang \\
\hline & & \\
\hline
\end{tabular}

\subsubsection{Tabel Aturan Sistem Pakar}

Tabel 3.3 Tabel aturan

\begin{tabular}{|c|c|c|c|c|c|c|c|c|c|c|c|}
\hline \multirow[b]{2}{*}{$\begin{array}{c}\text { Id } \\
\text { Gejala }\end{array}$} & \multicolumn{11}{|c|}{ Penyakit } \\
\hline & g్ & 吝 & 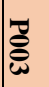 & 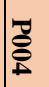 & 疋 & 몽 & క్రి & ఠ্ণ & ్ㅗㅇ & 㿣 & 电 \\
\hline G001 & $*$ & $*$ & $*$ & $*$ & $*$ & & $*$ & & & $*$ & \\
\hline G002 & $*$ & $*$ & $*$ & $*$ & & * & $*$ & $*$ & & $*$ & * \\
\hline G003 & $*$ & & & & $*$ & & $*$ & & & & \\
\hline G004 & $*$ & $*$ & & & & $*$ & & & & & \\
\hline G005 & $*$ & & & & & & & & & & \\
\hline G006 & $*$ & $*$ & & & & $*$ & & & & & \\
\hline G007 & $*$ & & & & $*$ & & $*$ & & & & \\
\hline G008 & $*$ & & & & $*$ & & * & & & & \\
\hline G009 & $*$ & & & $*$ & & & $*$ & & & $*$ & \\
\hline G010 & & $*$ & & $*$ & & $*$ & & & & $*$ & \\
\hline G011 & & $*$ & & & & & & & & & \\
\hline
\end{tabular}




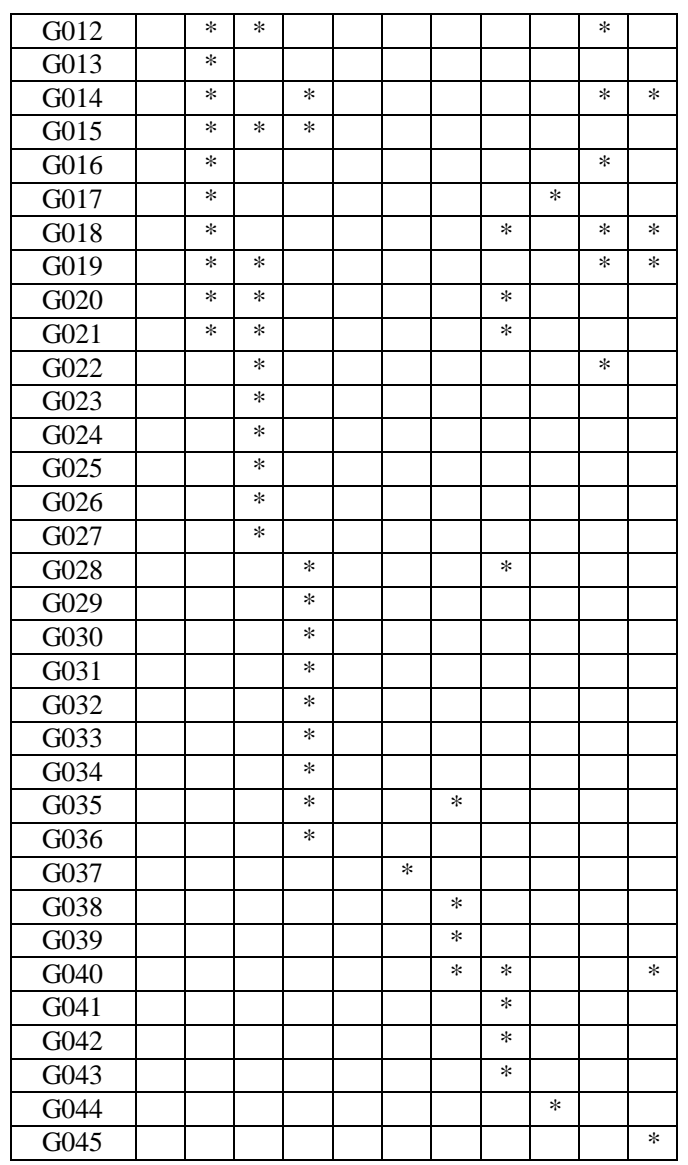

\subsection{Flowchart}

\subsubsection{Flowchart Sistem Pakar}

Alur flowchart sistem pakar seperti pada gambar 3.1

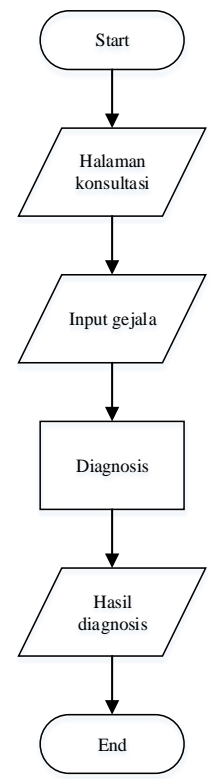

Gambar 3.1 Flowchart sistem
Gambar 3.2 flowchart sistem dimulai dengan tampilan halaman konsultasi, user atau pasien diharap untuk memasukkan atau memilih beberapa macam gejala yang pasien rasakan. Setelah itu dilakukan proses diagnosis berdasarkan gejala yang dipilih hingga proses selesai dan keluar informasi hasil diagnosis tentang penyakit yang di derita.

\subsubsection{Flowchart User}

Flowchart user ditunjukkan seperti pada gambar 3.2

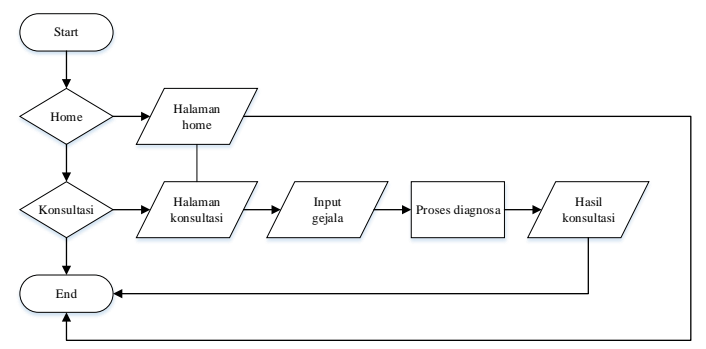

Gambar 3.2 Flowchart user

Gambar 3.3 flowchart user dimulai dengan halaman home yang berisi deskripsi singkat tentang penyakit autoimun, halaman konsultasi yang digunakan untuk user memilih gejala yang sudah dengan cara memberi checklist kemudian di proses oleh sistem berdasarkan aturan yang sudah dibuat, kemudian dilanjutkan proses Forward Chaining. Setelah proses selesai maka akan muncul informasi hasil diagnosis berupa penyakit yang di derita.

\section{HASIL DAN PEMBAHASAN}

\subsection{Implementasi}

Tahap implementasi ini yaitu penerapan sebuah sistem yang sebelumnya telah dirancang dan dianalisa. Tahap implementasi bertujuan untuk membuat tampilan dari website sistem pakar serta proses yang ada di dalamnya seperti penambahan, edit, dan hapus data.

\subsubsection{Halaman Utama User}

Halaman utama atau home ini adalah halaman yang pertama kali muncul ketika user mengakses website sistem pakar. User juga dapat mengakses menu lain seperti menu penyakit yang berisi daftar nama penyakit dari autoimun, dan menu konsultasi untuk user yang ingin mencoba diagnosa penyakit dari sistem pakar pada website. Tampilan halaman utama seperti pada gambar 4.1. 


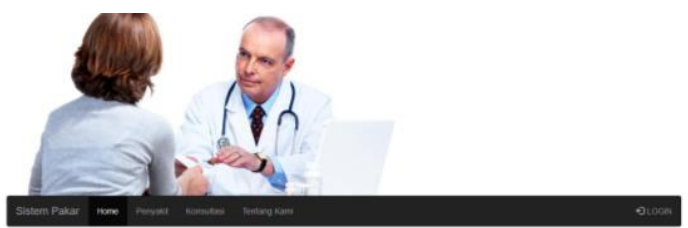

Sistem Pakar Penyakit Autoimun

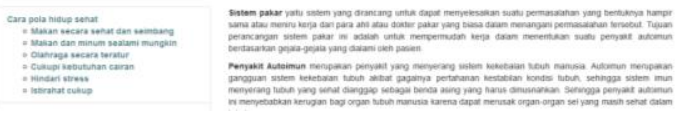

Gambar 4.1 halaman utama

\subsubsection{Halaman penyakit}

Pada halaman penyakit ini user dapat melihat nama-nama penyakit autoimun, serta gejala-gejalanya dari suatu penyakit tersebut. Tampilan halaman penyakit seperti pada gambar 4.2.

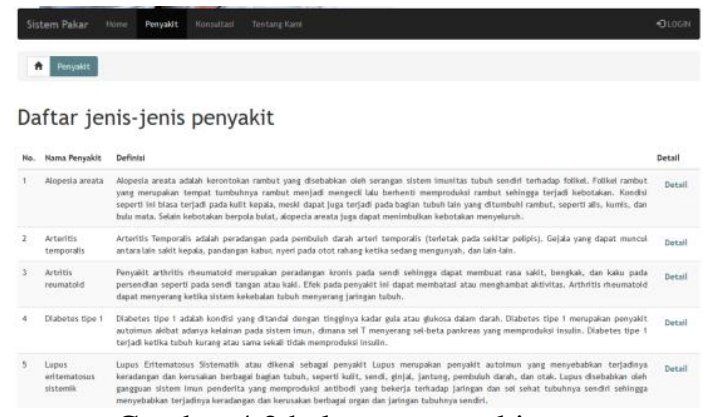

Gambar 4.2 halaman penyakit user

\subsubsection{Halaman Pilihan Konsultasi}

Halaman konsultasi menampilkan dua pilihan sebelum melakukan diagnosa penyakit yaitu dengan menggunakan metode forward chaining atau backward chaining. Tampilan halaman konsultasi seperti pada gambar 4.3.

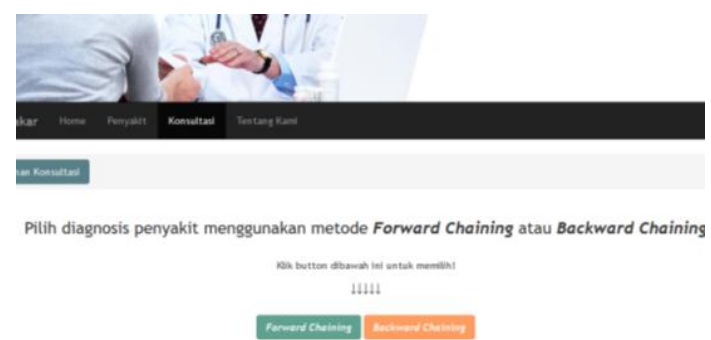

Gambar 4.3 halaman pilihan konsultasi

\subsubsection{Halaman Konsultasi Forward Chaining}

Halaman konsultasi menggunakan forward chaining, user diharapkan untuk mengisi data diri seperti nama dan jenis kelamin, serta juga memilih macam-macam gejala yang sedang dialami atau di derita oleh user atau pasien. Tampilan halaman seperti pada gambar 4.4.

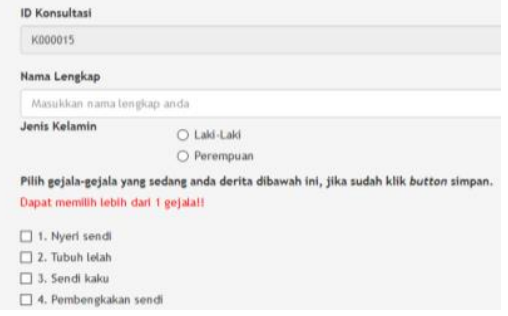

Gambar 4.4 halaman konsultasi forward

\subsubsection{Halaman Konsultasi Backward Chaining}

Halaman konsultasi menggunakan Backward chaining, user diharapkan untuk mengisi data diri seperti nama dan jenis kelamin, serta juga memilih macam-macam gejala yang sedang dialami atau di derita oleh user atau pasien. Tampilan halaman seperti pada gambar 4.5.

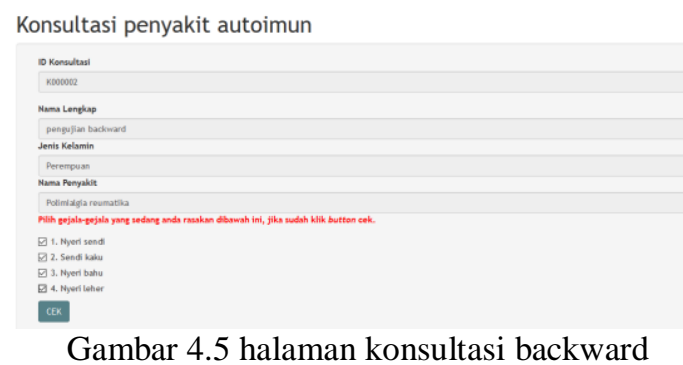

\subsubsection{Halaman Hasil Konsultasi}

Halaman hasil konsultasi ini akan secara otomatis muncul ketika user telah menyimpan atau telah selesai melakukan konsultasi. Pada halaman ini menampilkan seperti nama, gejalagejala yang dipilih oleh pasien, dan hasil diagnosis. Tampilan seperti pada gambar 4.6.

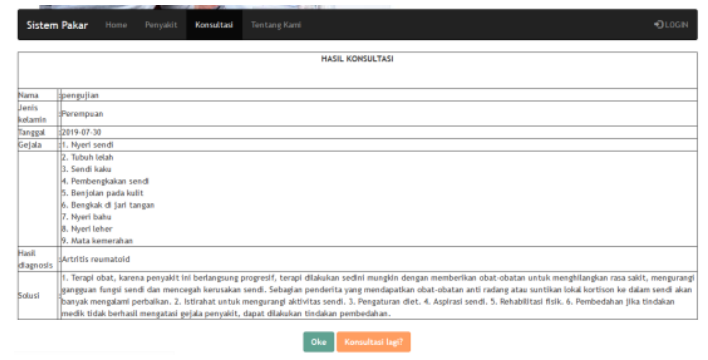

Gambar 4.6 halaman hasil konsultasi

\subsection{Pengujian \\ 4.2.1 Pengujian Penalaran Berbasis Aturan}

Pengujian penalaran digunakan untuk menentukan penyakit yang diderita user berdasarkan aturan yang telah ada dengan maksud untuk menemukan adanya kesalahan atau tidak pada sistem pakar sebelum sistem dipublikasikan untuk digunakan oleh masyarakat. Hasil pengujian seperti pada tabel 4.1. 
Tabel 4.1 Pengujian penalaran aturan

\begin{tabular}{|l|l|l|l|l|}
\hline No & Nama Penyakit & \multicolumn{1}{|c|}{ Data aturan } & \multicolumn{1}{|c|}{ Data sistem } & Hasil \\
\hline 1 & $\begin{array}{l}\text { Artritis } \\
\text { reumatoid }\end{array}$ & $\begin{array}{l}\text { G001, G002, G003, G004, G005, } \\
\text { G006, G007, G008, G009 }\end{array}$ & $\begin{array}{l}\text { G001, G002, G003, G004, G005, } \\
\text { G006, G007, G008, G009 }\end{array}$ & Sesuai \\
\hline 2 & $\begin{array}{l}\text { Lupus } \\
\text { sitematosus }\end{array}$ & $\begin{array}{l}\text { G001, G002, G004, G006, G010, } \\
\text { G011, G012, G013, G014, G015, } \\
\text { G016, G017, G018, G019, G020, } \\
\text { G021 }\end{array}$ & $\begin{array}{l}\text { G011, G002, G004, G006, G010, } \\
\text { G016, G017, G013, G014, G015, G019, G020, } \\
\text { G021 }\end{array}$ & Sesuai \\
\hline 3 & Penyakit seliak & $\begin{array}{l}\text { G001, G002, G012, G015, G019, } \\
\text { G020, G021, G022, G023, G024, } \\
\text { G025, G026, G027 }\end{array}$ & $\begin{array}{l}\text { G001, G002, G012, G015, G019, } \\
\text { G025, G026, G027, G023, G024, }\end{array}$ & Sesuai \\
\hline 4 & Sindrom sjogren & $\begin{array}{l}\text { G001, G002, G009, G010, G014, } \\
\text { G015, G028, G029, G030, G031, } \\
\text { G032, G033, G034, G035, G036 }\end{array}$ & $\begin{array}{l}\text { G015, G002, G009, G010, G014, G029, G030, G031, } \\
\text { G032, G033, G034, G035, G036 }\end{array}$ & Sesuai \\
\hline 5 & $\begin{array}{l}\text { Polimialgia } \\
\text { reumatika }\end{array}$ & G001, G003, G007, G008 & G001, G003, G007, G008 & Sesuai \\
\hline 6 & $\begin{array}{l}\text { Sklerosis } \\
\text { multipel }\end{array}$ & G002, G004, G006, G010, G037 & G002, G004, G006, G010, G037 & Sesuai \\
\hline 7 & $\begin{array}{l}\text { Spondilitis } \\
\text { ankilosa }\end{array}$ & $\begin{array}{l}\text { G001, G002, G003, G007, G008, } \\
\text { G009, G035, G038, G039, G040 }\end{array}$ & $\begin{array}{l}\text { G001, G002, G003, G007, G008, } \\
\text { G009, G035, G038, G039, G040 }\end{array}$ & Sesuai \\
\hline 8 & Diabetes tipe 1 & $\begin{array}{l}\text { G002, G018, G020, G021, G028, } \\
\text { G040, G041, G042, G043 }\end{array}$ & $\begin{array}{l}\text { G002, G018, G020, G021, G028, } \\
\text { G040, G041, G042, G043 }\end{array}$ & Sesuai \\
\hline 9 & Alopesia areata & G017, G044 & G017, G044 & Sesuai \\
\hline 10 & $\begin{array}{l}\text { Radang } \\
\text { pembuluh darah }\end{array}$ & $\begin{array}{l}\text { G001, G002, G009, G010, G012, } \\
\text { G014, G016, G018, G019, G022 }\end{array}$ & $\begin{array}{l}\text { G001, G002, G009, G010, G012, } \\
\text { G014, G016, G018, G019, G022 }\end{array}$ & Sesuai \\
\hline 11 & $\begin{array}{l}\text { Arteritis } \\
\text { temporalis }\end{array}$ & $\begin{array}{l}\text { G002, G014, G018, G019, G040, } \\
\text { G045 }\end{array}$ & $\begin{array}{l}\text { G002, G014, G018, G019, G040, } \\
\text { G045 }\end{array}$ & Sesuai \\
\hline
\end{tabular}

Dari hasil pengujian penalaran aturan pada tabel 4.1 dapat di simpulkan bahwa pengujian ini mendapatkan hasil yang sesuai semua dari 11 penyakit terhadap pengujian yang di lakukan.

\subsubsection{Pengujian Terhadap Pakar}

Pengujian terhadap pakar merupakan proses penentuan apakah hasil diagnosis penyakit berdasarkan beberapa macam gejala antara sistem yang dibuat dengan seorang pakar sama atau tidak. Hasil pengujian seperti pada tabel 4.2.

Tabel 4.2 Pengujian Terhadap Pakar

\begin{tabular}{|l|l|l|l|l|}
\hline No & ID Gejala & $\begin{array}{l}\text { Diagnosis } \\
\text { Sistem }\end{array}$ & $\begin{array}{l}\text { Diagnosis } \\
\text { Pakar }\end{array}$ & Hasil \\
\hline 1 & G001, G002, G003, G004, G005, G006, G007, G008, G009 & P001 & P001 & Sesuai \\
\hline 2 & $\begin{array}{l}\text { G001, G002, G004, G006, G010, G011, G012, G013, G014, G015, } \\
\text { G016, G017, G018, G019, G020, G021 }\end{array}$ & P002 & P002 & Sesuai \\
\hline 3 & $\begin{array}{l}\text { G001, G002, G012, G015, G019, G020, G021, G022, G023, G024, } \\
\text { G025, G026, G027 }\end{array}$ & P003 & P003 & Sesuai \\
\hline 4 & $\begin{array}{l}\text { G001, G002, G009, G010, G014, G015, G028, G029, G030, G031, } \\
\text { G032, G033, G034, G035, G036 }\end{array}$ & P004 & P004 & Sesuai \\
\hline 5 & G001, G003, G007, G008 & P005 & P005 & Sesuai \\
\hline 6 & G002, G004, G006, G010, G037 & P006 & P006 & Sesuai \\
\hline 7 & G001, G002, G003, G007, G008, G009, G035, G038, G039, G040 & P007 & P007 & Sesuai \\
\hline 8 & G002, G018, G020, G021, G028, G040, G041, G042, G043 & P008 & P008 & Sesuai \\
\hline 9 & G017, G044 & P009 & P009 & Sesuai \\
\hline 10 & G001, G002, G009, G010, G012, G014, G016, G018, G019, G022 & P010 & P010 & Sesuai \\
\hline 11 & G002, G014, G018, G019, G040, G045 & P011 & P011 & Sesuai \\
\hline
\end{tabular}

Berdasarkan dari hasil pengujian terhadap pakar pada tabel 4.4 dapat diambil kesimpulan bahwa hasil diagnosis antara pada sistem yang dibuat dengan seorang pakar menghasilkan hasil yang sesuai semua.

\subsubsection{Pengujian Pengguna}

Pengujian terhadap pengguna pada sistem pakar penyakit autoimun menggunakan metode forward chaining dan backward chaining berbasis web dilakukan dengan cara memberikan berupa kuesioner atau pertanyaan dan pengguna diharap memberikan penilaian. Pengujian 
dilakukan pada 11 orang, hasil pengujian seperti pada tabel 4.3 .

Tabel 4.2 Pengujian Pengguna

\begin{tabular}{|c|c|c|c|c|c|}
\hline No & Pernyataan & 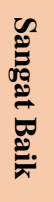 & 莽 & 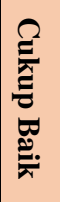 & 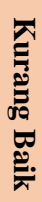 \\
\hline 1 & $\begin{array}{lr}\text { Website sistem } & \text { pakar } \\
\text { bermanfaat } & \text { bagi } \\
\text { pengguna } & \\
\end{array}$ & 3 & 8 & 0 & 0 \\
\hline 2 & $\begin{array}{l}\text { Tampilan website } \\
\text { sistem pakar bagus }\end{array}$ & 3 & 7 & 1 & 0 \\
\hline 3 & $\begin{array}{l}\text { Sistem pakar mudah } \\
\text { digunakan }\end{array}$ & 4 & 2 & 5 & 0 \\
\hline 4 & $\begin{array}{l}\text { Menu dari website } \\
\text { dapat berfungsi dengan } \\
\text { baik }\end{array}$ & 3 & 4 & 4 & 0 \\
\hline 5 & $\begin{array}{l}\text { Sistem pakar ini } \\
\text { membantu dalam } \\
\text { mendiagnosis penyakit } \\
\text { autoimun }\end{array}$ & 4 & 3 & 4 & 0 \\
\hline 6 & $\begin{array}{lr}\text { Tampilan } & \text { form } \\
\text { konsultasi mudah } & \text { muk dimengerti } \\
\text { untuk }\end{array}$ & 3 & 5 & 3 & 0 \\
\hline & Hasil & 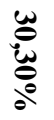 & $\underset{d}{\stackrel{t}{b}}$ & 崩 & $\begin{array}{l}\stackrel{8}{8} \\
\stackrel{8}{\circ}\end{array}$ \\
\hline
\end{tabular}

Hasil pengujian pengguna pada tabel 4.7 dapat diambil kesimpulan bahwa pengguna menyatakan sistem pakar penyakit autoimun mendapatkan hasil 43,94\% baik.

\section{KESIMPULAN DAN SARAN \\ 5.1 Kesimpulan}

Adapun kesimpulan yang di dapat dari pembuatan sistem pakar berbasis website ini yaitu :

1. Dari hasil pengujian penalaran aturan terhadap data aturan dengan data sistem dapat di simpulkan bahwa pengujian ini mendapatkan hasil yang sesuai semua terhadap pengujian yang di lakukan.

2. Hasil pengujian sistem pada web browser Google Chrome, Mozilla Firefox, dan Microsoft Edge, sistem ini dapat berjalan dengan baik sesuai dengan hasil yang di harapkan dan tidak terdapat kendala ketika melakukan pengujian.

3. Pengujian website sistem pakar menggunakan metode Black Box yang telah dilakukan dapat di simpulkan bahwa secara fungsional sistem sudah dapat menghasilkan output yang di harapkan terhadap hasil sebenarnya.

4. Hasil pengujian terhadap pakar dapat diambil kesimpulan bahwa hasil diagnosis antara pada sistem yang dibuat dengan seorang pakar menghasilkan hasil yang sesuai semua.
5. Hasil pengujian pengguna dengan memberikan kuesioner dapat diambil kesimpulan bahwa pengguna menyatakan sistem pakar penyakit autoimun $43,94 \%$ baik.

6. Hasil pengujian dari sistem pakar yang di bangun dengan judul "Analisis Mesin Inferensi Forward dan Backward Chaining untuk Diagnosis Penyakit Autoimun Berbasis Web" memperoleh hasil yang sesuai dengan aturan dan mampu berjalan dengan baik. Dari hasil uji keakuratan antara metode Forward Chaining dan Backward Chaining mempunyai keakuratan yang sama yaitu $75.77 \%$. Namun dari penggunaan kedua metode tersebut, metode Backward Chaining lebih mudah digunakan karena dimulai dari kesimpulan terlebih dahulu sehingga seseorang dapat mencobanya terhadap penyakit yang sedang dialami.

\subsection{Saran}

Adapun saran-saran yang dapat disampaikan adalah sebagai berikut :

1. Penambahan pengetahuan seperti penyakit, gejala, dan lain sebagainya yang baru terkait dengan penyakit autoimun.

2. Pengembangan sistem pakar pada perangkat android.

\section{DAFTAR PUSTAKA}

[1] Supartini, W. (2016). Sistem Pakar Berbasis Web Dengan Metode Forward Chaining Dalam Mendiagnosis Dini Penyakit Tuberkulosis di JawaTimur. KINETIK, Vol.1, No.3, Hal. 147-154.

[2] Turang, D.A.O. (2018). Aplikasi Sistem Pakar Berbasis Web Untuk Mendiagnosa Penyakit Syaraf Pusat Dengan Metode Forward Chaining. Kumpulan jurnaL Ilmu Komputer, Volume 05, 87-97.

[3] Lesmana, L.S. (2017). Penerapan Metode Forward Chaining Untuk Mendiagnosa Gangguan Autis Pada Anak Berbasis Android. Jurnal Komputer Terapan, Vol. 3, 19-32

[4] Azhar, S. Sari, H.L. Zulita, L.N. (2014). Sistem Pakar Penyakit Ginjal Pada Manusia Menggunakan Metode Forward Chaining. Jurnal Media Infotama, Vol. 10, 16-26.

[5] Honggowibowo, A.S. (2009). Sistem Pakar Diagnosa Penyakit Tanaman Padi Berbasis Web Dengan Forward Dan Backward Chaining. TELKOMNIKA Vol. 7, 187 194

[6] Bugis, N.R (2019). Sistem Pakar Diagnosis Hama Dan Penyakit Pada Tanaman Kelapa Menggunakan Metode Certainty Factor 
Berbasis Website. JATI (Jurnal Mahasiswa Teknik Informatika) Vol 3 No 1.

[7] Akil,Ibnu (2017). Analisa Efektifitas Metode Forward Chaining dan Backward Chaining Pada Sistem Pakar. Jurnal Pilar Nusa Mandiri Volume 13 No.1.

[8] Hutagalun, J.E dkk (2015). Sistem Pakar Dengan Metode Backward Chaining Untuk Pengujian Transistor Di Laboratorium Elektronika . Riau Journal Of Computer Science Vol.1, 9-15

[9] Herliana, Asti dkk (2018). Penerapan Inferensi Backward Chaining Pada Sistem
Pakar Diagnosa Awal Penyakit Tulang. JURNAL INFORMATIKA, Vol.5 No.1 April 2018, pp. 50 - 60

[10] Valid, V.Randi, dkk (2015). Rancangan Sistem Informasi Keuangan Gereja Berbasis Web Di Jemaat GMIM Bukit Moria Malalayang . E-Journal Teknik Elektro dan Komputer vol. 4 no. 7 (2015), ISSN : 2301-8402

[11] Willy dr. Tjin (2018, 9 Maret). Penyakit Autoimun. Diakses 10 April 2019 : https://www.alodokter.com/penyakitautoimun 